\title{
ORGANIZED CRIME IN THE FINANCIAL SYSTEM: FOREIGN EXPERIENCE
}

\author{
Mykhailo Markov ${ }^{1}$, Oleh Yemets ${ }^{2}$, Andrii Forostyanyi ${ }^{3}$
}

\begin{abstract}
The aim of the article is to analyse combating organized crime in the financial system of Ukraine and abroad; develop specific proposals to optimize the legislative provision of such activities on the basis of the study of positive foreign experience with a view to its further implementation into the relevant legal regulations of our state. The subject of the study is the interrogation of legal regulations of leading foreign countries that regulate the issue of combating organized crime in the financial sphere, the principles of the activities of these countries' respective organizations aimed at counteracting organized crime in the financial system, as well as state mechanisms for countering organized crime in the US financial system, European and other countries. Methodology. The study is based on general scientific and special-scientific methods and techniques of scientific knowledge. The dialectical method enabled to formulate the definition and determine the essence of the subjects in the system of combating crime, as well as mechanisms of anti-shadowing of the Ukrainian economy. The normative-dogmatic method enabled to interpret the content of legal regulations of domestic legislation that regulate the issue of organized crime in the financial system. The comparative legal method enabled to compare doctrinal approaches to the issue of organized crime in the financial system of Ukraine and abroad. The same method was used to analyse legislation of foreign countries regarding the issue under the study. Methods of analysis and synthesis enabled to study individual units of the institute of organized crime in the financial system. The sociological method was used to evaluate the results of the survey, conducted among employees of the National Police of Ukraine, on the need to take into account foreign experience in counteracting organized crime in the financial system. The method of legal modelling allowed making proposals regarding the improvement of the institute for combating organized crime in the financial system of Ukraine. Practical implications. The analysis of foreign experience of police activity, as well as special bodies and organizations, in combating organized crime in the financial system, carried out on the basis of a comparative legal study of principles, provided for in the international legal documents and their use in the police activities of democratic states, determined the expediency of their implementation in the police activities of the bodies of the National Police of Ukraine. Relevance/originality. The study proved that the legal basis for combating organized crime in the financial system of the examined states is the constitution and national laws, as well as specialized legal regulations, which define the status, rights and duties, the responsibility of employees of special subjects in combating organized crime in the financial system. In addition, in foreign countries, competencies are clearly distributed between national and special authorities to exclude duplication of powers. In view of the proved necessity of creating an effective system of counteraction to organized crime in the financial system of Ukraine, positive foreign experience implementation can become the driving force to strengthen the rule of law and legal order in our state.
\end{abstract}

Key words: foreign experience, organized crime, financial system, state security.

JEL Classification: F52, P43

\section{Introduction}

Ukraine declared its desire to enter the European Commonwealth of developed democracies, which have high standards of safety, well-being and standard of living of people, as well as the priority of human rights, the rule of law, and ensuring the inevitability of punishment

Corresponding author:

${ }^{1}$ National Academy of Internal Affairs, Ukraine.

${ }^{2}$ National Academy of Internal Affairs, Ukraine.

${ }^{3}$ National Academy of Internal Affairs, Ukraine. for those who committed a crime. Strengthening democratic institutions is impossible without reducing the negative effects of corruption and organized crime, which remain one of the greatest threats in our country today (Yevropeyskyi dosvid...).

Today, the state of the Ukrainian economy, transformations and processes that have taken place in the 
past, and especially in recent years, convincingly testify that the solution of the problems of socio-economic development has become strategic and global, has become one of the most important in the state. The overcoming of crisis phenomena, the struggle with the consequences of the global financial crisis, and the transition to sustainable economic growth require further elaboration of mechanisms for regulating the economy both at the state and at the regional level (Ruden). Legal instruments of a market economy began to be used extensively for the purpose of unlawful enrichment of certain segments of the population. As a result of the operation of the extensive network of fake business entities and their highly organized informal associations - converting centres annually suffer multimillion losses by the state, citizens, and legal entities. A fictitious enterprise appears as a tool for committing a whole range of mercenary crimes (tax evasion, smuggling, fraud with financial resources, etc.) (Hryhorovych, 2018). This situation is related to the fact that crime adapts to the transformations of the socio-economic structure of society and dynamically reacts to social and legal control in order to avoid it (Hryhorovych, 2018).

Therefore, economic crime is becoming an increasingly problematic, threatening phenomenon for Ukraine as an independent and young sovereign state. Existing long-standing imperfect economic relations are used by criminals to parasitize the body of a society, to secure significant own material revenues at the expense of non-payment of taxes, corruption, fraud with financial resources, legalization by means of "money laundering", occupation of prohibited types of economic activity, direct encroachment on all forms of property, and committing other crimes of economic orientation. Certainly, such acts should not and do not remain without a proper response from the state; they oblige their law enforcement agencies to carry out an uncompromising struggle with them (Tokarchuk, 2013).

The problem of counteracting organized crime in the financial system by a specialized body is theoretically allegedly solved - scientific works on the international experience of the creation and functioning of the relevant specialized bodies are enough. At the same time, attention is drawn to the lack of a systematic analysis of the feasibility of establishing such a body in Ukraine, taking into account Ukrainian specificity. Insufficiently highlighted is the question of the place and role assigned to the State Bureau of Investigations among other law enforcement agencies, including pre-trial investigation bodies. The problem is also compounded by the weakness of the financial control system in Ukraine and the CIS countries, in which it is virtually impossible to establish the origin of cash, large amounts are in circulation in cash (Tokarchuk, 2013).

In this regard, the study of foreign experience in the fight against organized crime in the financial system is becoming especially urgent today, which led to the selection of the relevant topic.
A significant contribution to the study of the problem of counteraction to organized crime in the financial system was made by foreign and domestic scientists: V. Volynets, P. Grigorovich, O. Juga, S. Dmitrov, L. Dolia, S. Egorichev, A. Yezhov, Zh. Zhukovsky, M. Zhuravel, F. Zhuravka, Y. Kobko, V. V. Kovalenko, S. Kravchuk, L. V. Krivonos, I. Lapinsky, O. Litvinov, M. Martynov, V. Muntian, O. Onyshchuk, S. Onishchenko, I. Osyka, S. Pavlenko, A. Parshutin, L. Polovinsky, A. Repecka, V. Ruden, V. Sevruk, S. Shandruk, O. Tokarchuk, N. Chorna, R. Chornyi, O. Shostko, O. Yunin.

The purpose of the article is to analyse the counteraction of organized crime in the financial system in Ukraine and abroad, as well as to develop concrete proposals to optimize the legislative provision of such activities by special international law enforcement agencies in the fight against crimes committed in the financial system by organized groups and criminal organizations.

\section{Presenting the main material}

The financial sector claims to be the undisputed global leader in economic globalization. The volumes of financial transactions have increased significantly and now dozens of times greater than the volume of trade turnover. Under the conditions of financial globalization, the market orientation of banks has intensified; the influence of new participants in financial markets - pension, investment, hedge funds, insurance companies, brokerage firms and others - has increased. In the end, financial globalization has contributed to the emergence of new opportunities for banks and increased the risks in their activities (Valiutne rehuliuvannia ta kontrol).

The main elements of the financial system are: national finances; local finance; finances of subjects of management of all forms of ownership; non-productive business finance; finances of the population; financial market; financial infrastructure.

Taking into account the main elements of the financial system in the current conditions of the functioning of the world economy, each country tries to achieve a high level of socio-economic development. As the processes of globalization give rise to increasing demands on the parameters of the national economy, Ukraine must develop a strategy for its development that can adequately reflect our state (Chorna, Chornyi, Shandruk; Yunin, Sevruk, Pavlenko, 2018) and counteract organized crime in the financial system.

Relevant radical socio-economic transformations that have taken place over the last decade have caused both positive and negative changes in modern Ukrainian society (Pavlenko, Sevruk, Kobko, 2017), which promotes the introduction of foreign experience in combating organized crime in the financial system at all levels by state and law enforcement agencies of Ukraine

The analysis of the main approaches to the definition of mechanisms for the shadowing of the Ukrainian economy 
provides grounds for arguing that the main mechanisms, according to scientists, are economic (improving the tax system, reforming the national financial control system, stimulating investment processes, creating favourable conditions for entrepreneurship development, fighting corruption, etc.) It is necessary to agree with the opinion of S. O. Pavlenko that corrupted ties, which are closely regulated in the legislative, executive, and judicial authorities, lead to the establishment of their dependence on criminal structures, which ensures the adoption of necessary decisions for them, in violation of current legislation or existing social norms (Pavlenko, 2016).

Correctly, in our opinion in this regard, O. Onyschuk notes: the effectiveness of measures to combat crime largely depends on achieving their uniformity within a coherent and consistent unified European policy. This condition is becoming more and more necessary in the face of such phenomena as organized crime, which is often international in nature, in the face of which national systems may prove ineffective. In modern Europe, where the boundaries between countries disappear, one cannot but consider the police and its powers in the international perspective. The problem is how effective the police are in the fight against crime, which increasingly crosses the state borders, including organized crime (Onyshchuk, 2011).

The current organized crime in the financial system not only poses a danger to the national interests of individual states but also represents a direct threat to international security, since it has become transnational in nature. First of all, it concerns countries with an unstable sociopolitical and economic situation that are at the stage of economic and political transformation, which includes Ukraine (Pohoretskyi, 2007; Pavlenko, 2017).

The leaders of organized criminal groups are paying particular attention to searching and establishing connections among corrupt officials engaged in law enforcement, regulatory activities in the economic sphere, judges, local authorities, and other officials competent to make important for organized crime solutions. This contributes to the increase in the number of corrupt officials who hold a responsible position. It should also be taken into account that corruption is characterized by a high level of latency (Dzhuzha, 2007; Pavlenko, 2013).

In the course of the research, during the questioning of the bodies of the National Police of Ukraine, it was established that $91 \%$ of our state should take into account foreign experience in combating organized crime in the financial system. Also, at this poll of respondents, the question was asked: the experience of foreign countries you would have taken for the implementation of the bodies of the National Police of Ukraine, which received the following answer: the United States - 21\%; Great Britain - 19\%; Poland - 15\%; Switzerland $-13 \%$, Italy $-11 \%$, France $-11 \%$ and $10 \%$ fell on the experience of other countries.

Therefore, taking into account the survey conducted, we will analyse the experience of the abovementioned countries, since practical workers are interested in exactly which entities carry out counteraction to organized crime in the financial system and regulate such activity by legal acts. Taking into account the above, we will provide reasoned conclusions regarding the implementation of positive foreign experience for Ukraine.

Consequently, the actors of counteraction to crime form a holistic in a functional and organizational relation system, connected by the common purpose and management in the field of counteracting crime. The complexity of this system is due, on the one hand, to the multifaceted tasks of ensuring security, prevention, termination, disclosure, and investigation of crimes and, on the other hand, the division of tasks between subjects of different levels, which is conditioned by the hierarchical construction of the system. This system is a complex social organization because the groups of homogeneous organs entering into it form relatively independent organizational formations that function on the basis of identical laws. Each of these formations is a subsystem of a larger system and at the same time consists of its subsystems (Lytvynov, 2015; Sevruk, 2017).

It should be noted that one of the most effective instruments of shadowing in many countries of the world is, first of all, systems and mechanisms for financial control over proceeds of illegal origin. For example: a) in Italy, a government decree introduced a ban on cash payments for large sums; b) in Germany, a mandatory declaration of settlements with non-residents has been introduced; c) in Japan - mandatory financial monitoring (financial institutions are obliged to notify authorized public authorities about major financial transactions). In addition, in Germany, reporting of suspicious transactions to financial monitoring bodies should not only banks and financial institutions but also lawyers, auditors (Muntiian, 1999; The Financial Times, 2011; WEU Council of Ministers, 1995; Onyshchenko, Lapinskyi, 2013).

So moving on to the coverage of the tasks, we will first analyse international special bodies and organizations that combat organized crime in the financial system. Today, there are many special law enforcement agencies, but we consider it necessary to distinguish between the three most effective ones that combat organized crime in the financial system.

Such international law enforcement organizations are primarily the International Criminal Police Commission (Interpol), the European Police Office (Europol), the Office for the Coordination of the Fight against Organized Crime and Other Dangerous Types of Crime on the Territory of CIS member-states (OCFAOC).

The existence of such structures can be defined as one of the organized responses of the world community to the illegal activities of such groups. At the regional level, the most developed such cooperation in Europe is the European Police Office (Europol) and the CIS countries - the Office for the Coordination of the Fight against Organized Crime and Other Dangerous Types of Crime on the Territory of CIS member-states 
(OCFAOC), in other geopolitical regions issue the creation of such organizations remains open. However, despite existing international acts of various levels and the work of international law enforcement organizations, the problem of combating transnational organized crime remains a worldwide issue (Etnicheskaia orhanyzovannaia prestupnost; Sevruk, 2018).

Europol is currently coordinating the work of the police services of all 28 European Union member states. Unlike national police forces, Europol does not have its own investigative bodies. Europol works closely with law enforcement agencies in 28 EU Member States and other non-EU partner countries and countries such as Australia, Canada, the United States, and Norway (Yevropol). Also, Europol has a relationship with the EU member states and with organizations that interact with Europol on the basis of cooperation agreements: Albania, Australia, Canada, Colombia, Iceland, Norway, Switzerland, Interpol and US law enforcement agencies: Bureau of Alcohol, Tobacco, Firearms and Explosives (ATF), Drug Enforcement Administration (DEA), United States Secret Service (USSS); Federal Bureau of Investigation (FBI); Immigration and Customs Legislation (ICE), and the Internal Revenue Service (IRS). This network has secured communication channels provided by Europol. In addition, Europol has two liaison officers deployed to Washington DC (USA) and Interpol Headquarters in Lyon, France (Yevropol).

The prospects for Ukraine's cooperation with Eurojust, the collective body of the EU, which aims to assist member states in the investigation of crimes and accelerate the coordination of the work of the competent authorities (those performing investigative functions), should also be taken into account. For Ukraine, it is important that Eurojust, for the fulfilment of its tasks, is authorized to conclude agreements and establish cooperation with third countries that are not EU members. Taking into account that the assistance and support of Eurojust in the criminal prosecution of criminals, members of organized communities, which it provides at the request of the countries, promotes the eventual disposing of organized groups and criminal organizations, the signing of the relevant international agreement with this organization is of the utmost importance. Moreover, the EU working bodies urge States to expand operational cooperation between the competent authorities, especially within the framework of bilateral and multilateral mechanisms and agreements (Further).

It is these aspects of the prevention of organized crime in the financial system, in particular, the transnational nature, reflected in the United Nations Convention against Transnational Organized Crime, which defines the following directions for combating organized crime in the financial system of the world:

The first area includes strategies to restrict the possibilities of committing criminal activity by reducing the existing or future opportunities for organized crime groups to operate on legitimate markets with the use of proceeds of crime through legislative, administrative, and other measures (paragraph 2, Article 2 of the Convention) (Konventsiia OON).

The second direction within the framework of crime prevention strategies is the need to reduce the level of vulnerability of the lawful economy in order to prevent the possible penetration of organized criminal organizations into it. Organized crime seeks to penetrate the lawful economy for a number of reasons, for example, in order to: a) legalize and invest the proceeds of crime; b) acquire respectability and social rehabilitation for "their" people - members of organized communities; c) gain control over the territory in which criminal groups carry out their operations to obtain maximum economic and political benefits and minimize the risk of detention, arrest, and conviction (referred to as "lawenforcement risk") (Repetskaia, 2001).

In implementing this strategic direction, it must be taken into account that the success of its implementation provides for the optimal combination of regulation and deregulation measures.

In 2004, the Council of Europe (within the framework of the Octopus program) published the "Review of the Model Case of Organized Crime (BPS)" prepared by the Group of Specialists on Criminal Law and Criminological Aspects of Organized Crime (PC-S-CO) (Aromaa, 2006).

Eight most effective strategies for the impact of organized crime (from the perspective of experts) that were implemented in different countries were selected. They are: the protection of witnesses, the transfer of the burden of proof of the legal origin of the property subject to confiscation, the offender (Shostko, 2007), listening to communication and electronic surveillance, analysis of crime through the study of its patterns and trends, international cooperation, criminalization of participation in an organized group in the material legislation, cooperation in the field of combating human trafficking, precautionary measures (so-called administrative approach (Shostko, 2008)).

Recognizing the high degree of harm caused by economic crimes to society and the world financial system, the Police Directorate of the General Secretariat of Interpol formed a department for combating financial and economic crime, which also includes a working group of the POPAC specializing in the control of income received as a result of criminal activity. The research of Flatwash Group is aimed at detecting suspicious financial transactions and money, property and property acquired in a criminal way, as well as in the CIS countries (Martynov, 2010). In some states, financial intelligence units have been formed that are integrated into the single Egmond network, which aims to intensify the exchange of information on economic crimes and the creation of a single international database of such crimes. The main attention is paid to crimes in the field of money laundering (Tokarchuk, 2013). 
Given the urgency of the problems associated with money laundering, the G20 Summit in Paris in 1989 created the Financial Action Task Force (FATF).

The FATF is an intergovernmental body that develops a policy to combat the legalization of proceeds from crime and promotes its implementation at the national and international levels. The FATF consists of 29 participating countries: Australia, Austria, Argentina, Belgium, Brazil, the United Kingdom, Greece, Denmark, Ireland, Iceland, Spain, Italy, Canada, Hong Kong (China), Luxembourg, Mexico, the Netherlands, Germany, New Zealand, Norway, Portugal, Singapore, the United States of America, Turkey, Finland, France, Switzerland, Sweden, and Japan and two regional organizations: the European Commission and the Gulf Cooperation Council. The FATF cooperates with other international organizations working in this area, such as the United Nations Office on Drugs and Crime, the Council of Europe, the Asia-Pacific Group Against Money Laundering, and the Caribbean Financial Action Task Force. The FATF Secretariat is located in the Organization for Economic Cooperation and Development (OECD) (Dolia, 2001).

The main task of the FATF is to ensure that all financial centres adopt the international standards in the area of prevention, detection, and prosecution of money laundering. To accomplish this task, FATF has developed Forty Recommendations, which are international standards and constitute the basic structure of anti-money laundering measures to be applied at the global level. Forty recommendations define the general principles of action that should be reflected in the national legislation of the countries on the following issues: criminal liability, the administration of justice, the application of administrative and civil enforcement measures, the functioning of the financial system, issues of international cooperation, etc. They emphasize the need to strengthen national legal actions aimed at the counteraction to money laundering, to increase the role of the financial and banking system in this matter, and to expand international cooperation. Although recommendations are not an international binding convention, many countries have committed themselves to state regulation of the fight against money laundering.

The FATF focuses on analysing global financial flows, banking and financial systems and money laundering practices, trying to identify weaknesses in combating this phenomenon. The said body continuously monitors and analyses how the FATF member countries are faced with money laundering and processes to bring FATF legislation into line with the laws of certain countries that have expressed their support for the global effort to combat money laundering (Kryvonos, 2014).

In the case of negative findings from the results of this analysis, the FATF has the right to apply certain measures of influence that can be expressed in the country's alert, making the country a "blacklist" (the list of non-FATF countering countries), as long as to apply recommendations on limiting cooperation with offending countries. The consequence of such sanctions may be restrictions and termination of settlements, blocking funds on correspondent accounts of banks and accounts of enterprises, closing these accounts etc. (Cabinet of Ministers of Ukraine and the National Bank of Ukraine).

In addition to the above-mentioned bodies, such as Interpol, Europol, OCFAOC, Eurojust, FATF, UN, there are also other special international organizations that coordinate work in the field of prevention and counteraction of organized crime in the financial system. Such organizations are today:

1. Egmont Group (Egmont Financial Intelligence Unit)

2. MONEYVAL - Committee of Experts on the Evaluation of Anti-Money Laundering Measures and the Financing of Terrorism.

3. Eurasian Group on Combating Money Laundering and Financing of Terrorism (EAG).

4. Basel Committee (Committee on Regulation and Supervision of Banking).

5. The Wolfsberg Group is an interbank association.

6. International Monetary Fund.

7. World Bank.

8. European Bank for Reconstruction and Development.

Consequently, after analysing the above-mentioned special bodies and organizations for combating organized crime in the financial system, one should consider the direct positive experience of the states, which effectively counteract this day.

First of all, one such state is the United States.

Professor of Chicago-Kent College of Law Philip $\mathrm{N}$. Hablutzel has analysed the development of current US legislation in the area of counteraction to money laundering, including amendments made to American legislation after the events of September 11, 2001. In particular, the legal definition of the legalization of criminal proceeds was expanded, and now the crime is recognized as conducting the operation itself with funds of doubtful origin, regardless of the fact of proving a predicate crime. The criminal responsibility for the legalization of criminal "profits in the United States is established both at federal level and in each individual state, including the so-called "structuring" the distribution of a large amount of money for small amounts in order to avoid checks by the government, which is regarded as deceit in order to hide the Riley transaction. It also expanded significantly the list of financial and non-financial institutions, which are obliged to report to public authorities about dubious financial transactions; and imposed a duty for lawyers and auditors to report suspicious financial and property transactions of their clients. Violations of these requirements impose strict civil and criminal liability, one of the types of punishment of which is a fine in the amount that can twice exceed the amount of suspicious transaction (Osyka, 2003). 
For example, in the United States, special FBI units (FBI SWATs) are used to fight organized crime (gangs, syndicates, mafia) - assault groups with special army armaments that exist in each of the 56 regional branches of the FBI and use a special tactic to neutralize criminals during special operations, in which skills and abilities are beyond the reach of ordinary policemen (Volynets, 2014).

The US experiencein combatinglegalization(laundering) of criminal profits proves the following. In the United States, the legal definition of the legalization of criminal proceeds was expanded, and now the crime is recognized as conducting the operation itself with funds of doubtful origin, regardless of the fact of proving a predicate crime. Criminal liability for the legalization of criminal proceeds in the United States is established both at the federal level and in each individual state. A separate responsibility for the establishment and for the so-called "structuring" - the distribution of a large amount of money for small amounts in order to avoid checks by the government. Such activity is regarded as misleading in order to conceal suspicious transactions (Polovynskyi, 2008).

Since the legalization of criminal proceeds consists in the implementation of any cash operations, countering the legalization is, first of all, in tracking cash flows and cashless funds. One of the most effective ways of tracking cash flow is monitoring payments. Today, in the United States, two of the most common forms of settlement are working - with checks and credit cards. Both forms of settlements are through the system of the federal reserve and the central bank, which monitor the payments with the use of checks and credit cards. The American strategy to combat money laundering cannot be called rational and rational. Despite legislative innovations, we cannot say that the federal government has managed to prosecute all illegal transactions with the money of dubious origin. In addition, the issue of interaction between law enforcement and controlling bodies is not resolved. Thus, in the strategy of the American government to combat the legalization of criminal proceeds, 10-12 different federal agencies are responsible for different directions of its implementation, and the mechanism of their cooperation is not developed (Zhuravel, 2010; Tokarchuk, 2013).

But after September 11, 2001, this law has expired, and informing banks of clients, including individuals, about the information provided to law enforcement authorities on their request, is prosecuted by criminal law. The jurisprudence goes the same way. According to the latest US Supreme Court decision, bank account information is not the information covered by the rules for the non-disclosure of private data in accordance with the 4th Amendment to the US Constitution, which cleans the privacy of a person from third-party interference. Now banks are obliged to provide law enforcement authorities with any information about their clients on the requirements of law enforcement agencies (Osyka, 2003).

The strategy of the American government to combat the legalization of criminal proceeds has also changed.
Today, it aims at combating the financing of terrorism and depriving the financial foundation of organized criminal groups. If earlier law enforcement agencies have tracked the sources of doubtful income, now focus is on the sources of their use. Recent studies conducted in the United States show that even money that has been obtained quite legitimately can be used for criminal purposes. This is especially true of the activities of various deaneries and religious organizations that collect donations and spend them on organizing terrorist acts or other criminal activities. This form of activity is very attractive to terrorists and criminals since it plays the role of a fairly effective cover. Considerable attention was paid to the detection and confiscation of hidden funds obtained as a result of criminal or terrorist activities, the prevention of the legalization of criminal proceeds and predicate crimes - the source of criminal proceeds.

Attention is also paid to the study of criminal statistics, in particular, regarding the financial analysis of legalization operations to find out the actual size of profits of specialists in the economy who advise offenders, which unofficially amounts to 4,8 or $12 \%$ of the amount to be legalized. Today, such statistics are expressed by the amount of confiscated property and the number of persons convicted for this crime. So, in 2001, 639 moles were confiscated and in the fiscal year 2001-2002, nearly 1,000 people were prosecuted, only 50 of which were sentenced to more than 3 years' imprisonment. Professor Hablutzel called the exchange of operational information an important element in counteracting the legalization (laundering) of criminal profits. Even after the events of September 11, 2001, the United States, even the traditional rivals of the FBI and (RU) began to actively exchange data, but at the international level, this problem remains acute. Negative factors still lack trust in the agencies of individual countries and warnings about deliberate misinformation and misuse of the information received. For the development of international cooperation in this area, the Centre for the Investigation of Financial Crime, the tasks of which is to establish ties with law enforcement agencies of different states and organise information interchange with them by signing relevant international agreements and amendments to domestic legislation (Osyka, 2003).

In the UK, the first anti-money laundering provisions were contained in those related to illicit drug trafficking (1986). In 1990, this country became the first European state to ratify the Council of Europe Convention on Laundering, Search, Seizure and Confiscation of the Proceeds from Crime (Strasbourg Convention) (Yehorycheva, 2014).

For example, in the United Kingdom, individual elements of the currency control system continue to be used. Yes, there are restrictions on the circulation of currency values, control over foreign currency investment, the fight against the legalization of proceeds of crime, which involves the Joint Working Group and 
the National Bank of the United Kingdom for Financial Investigations are being actively pursued.

According to the UK's experience in combating the legalization of criminal proceeds, each bank has an authorized employee responsible for complying with the requirements of banking legislation in the area of combating the legalization of criminal proceeds. Each year an authorized employee must undergo retraining on new legislation, means, and methods of counteraction in this area. A bank employee who has not taken appropriate anti-money laundering measures is liable for criminal law (Kravchuk, 2010).

In the UK, a new form of work with informants was introduced. From now on, all information related to money laundering is sent to a centralized authority. The payment for the services of informants was assumed by banks $-75 \%$ and the Ministry of Internal Affairs - 25\%. This should help increase the effectiveness of combating the legalization of criminal proceeds (Tokarchuk, 2013).

According to Polish experience, in Poland in the area of combating legalization (laundering) of criminal proceeds, the legal basis is the Law "On Tax Control" and the Law "On Counteraction to the Legalization of Dirty Money", the relevant provisions of the Criminal and Currency Codes. The Law "On Tax Control" in the structure of the Ministry of Finance created the Bureau. In accordance with the Law "On Counteraction to the Legalization of Dirty Money”, the Department of Finance established the Financial Information Department and entered the post of General Inspector of Financial Information, which has the status of Deputy Minister. Thus, today in the structure of the Ministry of Finance of Poland, in parallel, there are two departments: the Department of Financial Information and the Bureau of Tax Control (Zhukovska, 2008).

On July 27, 2002, a new law "On Foreign Currency" was issued in Poland, which regulates the execution of foreign exchange transactions. This law abolished all restrictions on the movement of funds between Poland and the EU countries. At the same time, the law provides for some restrictions regarding the movement of funds from non-EU countries. Currency restrictions can be removed by obtaining currency permits that are of two types: general and private. The general currency permits are issued by the Ministry of Finance, and private ones are the National Bank of Poland. The main measure of currency regulation was the transition to a flexible exchange rate and the introduction of the "free-swimming" regime in 2000. Thus, the government and the National Bank of Poland were able to solve the problem of the impossibility of combining three goals, namely: stability of the exchange rate, capital mobility, and monetary autonomy (Zhuravka, 2008).

In the structure of the Ministry of Finance, the Taxation Bureau was established, which started its activity in 1998, and after the introduction of amendments to the Law on Tax Control of June 7, 2002, the scope and functions of the Bureau were significantly expanded through a combination of tax and customs control functions. Related staff members of the Bureau were provided with appropriate police rights, close to carrying out operational and investigative measures (Osyka, 2003).

The tax office has a vertical structure with the Main Office in Warsaw, tax offices in 16 voivodships and prefectures of tax records in the counties. At present, the Bureau employs over 350 people throughout Poland. The responsibilities of the Bureau include: counteracting violations of current legislation in the field of external and internal commodity circulation; detection of violations and crimes in the field of management of public funds and funds derived from the European Union and international financial organizations (after the accession of Poland to the European Union income from various organizations began, at the same time, there were cases of non-economic spending, embezzlement, and other means of theft of these funds); prevention of corruption of public servants of the Ministry of Finance; control over declarations of income and property status of civil servants, including employees of structural subdivisions of the Ministry of Finance; the disclosure of crimes that encroach upon Polish national culture, archival resources and intellectual property; detection of property obtained by criminal means and that which is subject to confiscation; revealing mechanisms for transporting money into the territory of Poland, which are derived from crimes; conducting analytical work on these types of crimes (Tokarchuk, 2013).

But, according to Polish experts, even the best domestic laws in the area of counteraction to legalization cannot be sufficiently effective without international cooperation since criminals are very rarely confined to the territory of one state, causing problems of a jurisdictional and organizational nature. Therefore, the domestic legislation of the states should be adapted to the needs of international cooperation, that is, to have common features. First, on the system of legal aid, as well as the exchange of information between the police, customs, and tax services. Thus, the Ministry of Internal Affairs of Ukraine and Poland have an agreement on mutual assistance, and in August 2001 a Protocol was signed on the cooperation between the Main Commandant of Police of Poland and the Ministry of Internal Affairs of Ukraine, which specified the persons responsible for separate areas of crime control, including for counteraction to legalization of money. The experience of solving current issues of operational work under the Protocol has shown excellent effectiveness of direct contacts between law enforcement officers of different states. Secondly, it is necessary to create an effective and harmonious system of extradition of criminals and property belonging to them; thirdly - to establish free access to information and documents in the territory of other states through the conclusion of bilateral agreements on the basis of reciprocity (Osyka, 2003). 
In Switzerland, since 1990, articles on money laundering have been introduced into the Criminal Code, which provide for maximum sentences for this crime in the form of deprivation of liberty for a term up to three years, in serious cases - up to five years together with payment of a significant amount of monetary In 1997, the Federal Law on Money Laundering was adopted (in other words, the Anti-Money Laundering Act), which forms a part of the legislation regulating the activities of financial intermediaries. It established the main obligations of financial institutions to counteract the legalization of criminal incomes and gave supervisors the right to elaborate detailed rules for the banking and non-bank financial market sectors. In general, this regulation envisages strengthening control over banks and other financial intermediaries, their obligation (and not the right, as was recorded in 1994) to report suspicious transactions, to conduct customer identification, and therefore means a significant restriction of banking secrecy, the law of which was adopted in 1934 (Yehorycheva, 2014).

In accordance with the requirements of the law, before establishing business relations with clients, financial institutions should identify them on the basis of valid documents, as well as identify the real beneficiaries. They also have the duty to find out the economic background and purpose of conducting unusual and suspicious transactions, to demand necessary documents from clients and to store them for ten years. The Money Laundering Reporting Office Switzerland (MROS), a federal police service, has also been set up under the Anti-Money Laundering Act. When communicating to this body about transactions for which there is a solid suspicion of their connection with money laundering or terrorist financing, financial intermediaries are obliged to "freeze" the relevant assets for a period of up to five days, while they are exempted from disclosure responsibility secrets and the consequences of such actions (Yehorycheva, 2014).

In 1995, the Italian Currency Office created a special department to combat the prevention of the use of financial institutions to launder criminal proceeds (Kolesnikov, 1999). Italy's current legislation obliges banks and other intermediary institutions to maintain detailed documentation on resident currency transactions in order to avoid attempts to launder money. Gamma-Vassali law (1990) criminalized the operation of "laundering" and for the first time in the world practice has defined the concept of "criminal organization of the mafia type." The Italian Criminal Code provides for sentences of 7 to 12 years' imprisonment and fines. The punishment can be increased if the same actions are committed by officials while using their official position. As a result of legislative changes in 1990, the state is obliged to monitor the detection and termination of attempts to legalize criminal money. The monitoring system assumes that the transfer of any amount abroad is accompanied by the simultaneous declaration of income (Kryvonos, 2014).
In France, Traitement du Renseignement et Action contre les Circuits FINanciers clandestins (TRACFIN), FIU of the Ministry of Economy, Finance and Industry of France, which operates the Information Clearinghouse, is a central organ of the system for combating and preventing the legalization of criminal incomes and combating the financing of terrorism. TRACFIN (TRACFIN) is the body to which information about the accounts opened in banks of individuals and legal entities is provided. The French law does not contain requirements to provide information on financial transactions in the event that the amount of the financial transaction exceeds a certain limit. Signs for providing financial data monitoring entities to TRACFIN on financial transactions are motivated by the suspicion that it is being carried out in order to legalize criminal proceeds, namely, funds that can relate to: organized crime, drug trafficking, financing terrorism, and corruption. Particular attention is required for financial transactions worth more than 15 thousand euros if they are intricate or have no economic sense. Crimes related to legalization (laundering) of funds are punishable by imprisonment for a term of 8 years and a monetary fine (Kovalenko, Dmytrov, Yezhov, 2007).

So, after analysing the effective experience of the United States, Great Britain, Poland, Switzerland, Italy, and France in combating organized crime in the financial system, we consider it necessary to distinguish, in our opinion, interesting provisions concerning the subject matter and other states such as Spain, Ireland, Cyprus, Greece, Austria, Belgium, Japan, Hong Kong.

In Spain, the Criminal Code (Article 301) refers money laundering to a section on bribes and similar offenses. It includes all serious crimes with a term of imprisonment of more than three years. The Money Laundering Act includes combating income from organized crime, terrorism, drug trafficking.

In Ireland, the Criminal Law Act of 1994 obliges all financial institutions to require new clients who will carry out large transactions, documentary evidence of the origin of money.

The Cyprus Banking strategy is based on the "know your client" principle and seeks to identify individuals who have several trust accounts that are not compatible with their business form, or accounts receivable from a large number of different private recipients, as well as those customers who try to open an account for a large sum even on disadvantageous conditions. According to this strategy, bankers should know the origin of funds, the history of all accounts opened in the bank, the frequency of customer appeals to the bank.

The legislation of Greece provides for the identification of clients in the case of contracts, opening accounts, hiring safes, lending on bail; at the same time, identification does not require insurance operations for insignificant amounts and terms and related to pension insurance.

In Austria, the only one in the European Union that allowed anonymous bank accounts to be issued, a FATF 
program has been developed to phase out them. In particular, the Austrian Criminal Code declares the crime of laundering all assets derived from the commission of serious crimes involving imprisonment for a term of more than three years.

The Belgian financial authorities, strictly controlling the movement of money, must check all transactions worth more than 10 thousand euros. The Special Money Laundering Act of January 11, 1993, includes terrorism, organized crime, drug trafficking, weapons, the use of underground labour, trafficking in human beings, prostitution, the illegal use of hormones in animals, human trafficking, serious and organized tax fraud that violates financial interests. The European Community, corruption, untypical investments, false bankruptcy. In accordance with the royal decree of June 11, 1993, a special structure - the Financial Information Sector (CTIF) - was created under the auspices of the Ministries of Finance and Justice. This body analyses, with the involvement of relevant experts, the declarations of banks, exchanges, and other financial institutions about suspicious transactions, uses information from police, customs and other government agencies (Kryvonos, 2014).

Until recently, only legislation on the laundering of illicit drug trafficking was settled in Japan's legislation. These issues were regulated by the Law on Special Exceptions to the Law on the Control of Narcotic Drugs and Psychotropic Substances (1991), which has been abbreviated as the Law on Drugs. In 1998, its provisions were implemented to the Basic Principles of Supervision over Financial Institutions, developed by the Financial Supervision Agency established in the same year (since 2000 - Financial Services Agency). Simultaneously, an amendment to the Law on currency exchange and foreign trade ordered banks and currency exchange operators perform in some cases identification of customers but did not provide any responsibility for non-compliance. The adopted in 1999 the Law against Organized Crime in Japan was expanded range of offenses relating to money laundering and later those provisions were included in the Supervisory Framework (Yehorycheva, 2014).

In Hong Kong, it has long been considered the most corrupt financial capital of the world in 1973 created an independent commission to combat corruption, subordinate to the Governor of Hong Kong, which assigns each person the commission investigating the post (Parshutin, 2015).

Therefore, it can be argued that the current system of measures to combat organized crime in the financial system is based on the following basic principles:

- a minimum amount of financial transaction over which all transactions of a certain type to be registered designated law institutions and individuals to further test possible - usually a sum of 10 thousand USD;

- developed and introduced into the action list of features that allow you to determine whether or related financial transaction carried out among those held for money laundering or terrorist financing;
- responsibility for informing law enforcement or regulatory agencies regarding suspicious transactions imposed on certain subjects through which financial transactions are conducted;

- governments provide one of the executive power to coordinate the activities of all law enforcement and regulatory agencies in combating the legalization of proceeds and terrorist financing, acquiring the status of FIU (Yehorycheva, 2014).

Almost all countries have created special organizations dealing with money laundering. In the United States, this is the Department for Fighting Financial Crimes, created under the US Department of the Treasury; in Japan - the Financial Analysis Centre, the Financial Intelligence Office of Japan, in Greece - the Special AntiMoney Laundering Board, in Argentina - the Financial Information Committee, in Brazil - the Financial Supervisory Authority. In Mexico, there are two special organizations -the Directorate General for Transaction Investigation and the Anti-Money Laundering Agency. The problem of money laundering in financial institutions in Belgium is the Ministry of Finance and Justice created the Financial Information Sector, which analyses suspicious transactions, as well as reports from police, customs, and other government agencies and, if necessary, checks the information suspend suspicious transactions (Kryvonos, 2014).

In conclusion, it should be noted that the counteraction to organized crime in the financial system requires special attention and special approaches, as scientists who develop methodological recommendations and practical workers who use them during detection, termination, and prevention (Sevruk, 2016).

An analysis of the foreign experience of police activity, as well as special organs and organizations on combating organized crime in the financial system, namely, on the basis of a comparative legal analysis of the principles defined in international legal instruments and their use in the police activities of democratic states, determined the feasibility of their implementation in the police activities of the bodies of the National Police of Ukraine.

This will allow departing from the standards of the Soviet law enforcement system and updating the approaches to combating organized crime in the financial system in Ukraine due to the necessity of using the foreign experience of law enforcement bodies and the implementation of the international legal framework taking into account national interests and peculiarities of domestic experience.

Currently, a number of issues exist in the practical activities of this direction. So, given the results of the survey respondents determined that the state of scientific elaboration combating organized crime in the financial sector needs to be improved by identifying conceptual-categorical apparatus of organized crime in the financial sector (72\%), the study of organized crime in the financial sector as a criminological phenomenon 
(68\%), others (63\%). The most important thing for Ukraine in this context is the study of the foreign experience of foreign countries that have succeeded in this area $-87 \%$ of respondents (Androsovych, 2018). From this line, we consider it necessary to highlight the position of S. Pavlenko that a society raised in a low moral environment cannot effectively counter organized crime in the financial system. Therefore, the priority measures of state policy should be the education of moral qualities of the individual (Pavlenko, 2015).

Of course, in the current economic situation in Ukraine, we cannot adopt all the positive foreign experience in combating organized crime in the financial system, but the study of its individual components and their implementation in practice of law enforcement bodies of Ukraine will improve performance when combating organized crime in the financial system.

\section{Conclusion}

Summing up the above, there is the question of the need to create an effective system for combating organized crime in the financial system in Ukraine. Therefore, the use of foreign experience of state mechanisms for the prevention and counteraction of organized crime in the financial system allows formulating a complex of effective national levers of state regulatory influence on counteracting this type of crime.

The problem of organized crime in the financial system has become international in recent years. At the same time, the international community recognizes that organized crime in the financial system has become a global threat to economic security, which is why states are required to adopt agreed measures to combat this socially dangerous activity, both at the national and international levels.
Therefore, it is necessary to agree on this issue V. Sevruk, the proposed system should have interstate status and concentrate information on all law enforcement agencies and special international law enforcement agencies (Interpol, Europol, PCSCO, Eurojust, FATF, Egmont Group, MONEYVAL, Eurasian Group on Combating Money Laundering and Financing of Terrorism (EAG), Basel Committee (Banking Regulatory and Supervisory Committee), the Wolfsberg Group, the International Monetary Fund, the World Bank, the European Bank for Reconstruction and Development). Such a system will create some work to overcome this phenomenon on a global scale, for those who commit counteraction to organized crime in the financial system - prerequisites for international cooperation on counteraction in this whole (Sevruk, 2017).

It should be noted that our analysis of foreign experience in the fight against organized crime in the financial system of the United States, European, and other states allows you to highlight a number of points that characterize the above aspects of such a counteraction: the legal basis of these states are the constitution and national laws, as well as specialized legal acts, which defines the status, rights and responsibilities, the responsibility of employees of special actors to counter organized crime in the financial system. Also, in foreign countries, there is a clear division of competences between national and special authorities, which excludes duplication of powers.

Taking into account the above, it should be noted that the implementation of positive foreign experience regarding the practice of counteracting organized crime in the financial system of the activity of law-enforcement bodies in the current state-legal reality of Ukraine may be a positive driving force for strengthening the rule of law and law in the Ukrainian territory.

\section{References:}

Yevropeyskyi dosvid zapobihannia orhanizovanii zlochynnosti: teoretychni pytannia [The European experience of preventing organized crime: Theoretical issues]. Retrieved from: http://referat-ok.com.ua/pravo/jevropeiskiidosvid-zapobigannya-organizovanii-zlochinnosti-teoretichni-pitannya. (in Ukrainian)

Ruden, V. V. Perspektyvy ta priorytety rozvytku sotsialno-ekonomichnoi systemy Ukrainy [Perspectives and priorities of the development of the socio-economic system of Ukraine]. Retrieved from: http:/ intkonf.org/ ruden-vv-perspektivi-taprioriteti-rozvitku-sotsialno-ekonomichnoyi-sistemi-ukrayini/ (in Ukrainian)

Hryhorovych, P. O. (2018). Zahalna kharakterystyka kryminalnykh pravoporushen, poviazanykh iz fiktyvnym pidpryiemnytstvom [General characteristics of criminal offenses related to fictitious business]. Aktualni problemy operatyvno-rozshukovoi protydiyi zlochynam : materialy nauk.-prakt. Seminaru (pp. 21-23). (Dnipro, May 24, 2018). Dnipro: Dnipropetrovsk State University of Internal Affairs. (in Ukrainian)

Sevruk, V. H. (2017). Aspekty protydii zlochynam, shcho vchyniaiutsia v ekonomichnii sferi orhanizovanymy hrupamy i zlochynnymy orhanizatsiiamy, sformovanymy na etnichniy osnovi [Aspects of counteraction to crimes committed in the economic sphere by organized groups and criminal organizations formed on an ethnic basis]. Proceedings from International Scientific and Practical Conference on Shadow Economy: World tendencies and Ukrainian Realities (pp. 323-327). (Kyiv, June 23, 2017). V. V. Cherniei, S. S. Cherniavskyi, V. I. Shakun et al. (Eds.). Kyiv: National Academy of Internal Affairs. (in Ukrainian)

Tokarchuk, O. (2013). Zarubizhnyi dosvid borotby z ekonomichnoiu zlochynnistiu [Foreign experience in combating economic crime]. Aktualni problemy derzhavnoho upravlinnia, 1, 147-150. (in Ukrainian)

Valiutne rehuliuvannia ta kontrol [Currency regulation and control]. Neobkhidnist borotby $z \ll b r u d n y m y »$ hroshyma» [Need to fight "dirty" money]. Retrieved from: http://posibniki.com.ua/post-71-vidmivannya-grosheycherez-bankivsku-siste-mu-ta-viyavlennya-ioh (in Ukrainian) 
Chorna, N. P., Chornyi, R. S., Shandruk, S. K. Socio-economic development of Ukraine: New challenges and threats. Naukovyi visnyk Polissia, 1(13), part 1, 100-107.

Yunin, O., Sevruk, V., Pavlenko, S. (2018). Priorities of economic development of Ukraine in the context of European integration. Baltic Journal of Economic Studies, 4(3), 358-365. doi: 10.30525/2256-0742/2018-4-3-358-365

Pavlenko, S., Sevruk, V., Kobko, Y. (2017). Training police officers in the conditions of reforming the system of education of the Ministry of Internal Affairs of Ukraine in accordance with European standards. Science and Education, 6, 142-150.

Pavlenko, S. O. (2016). Shliakhy udoskonalennia pravovoho rehuliuvannia protydii osobam, vidnesenym do katehorii «zlodiiv u zakoniv» v Ukraini [Ways to improve the legal regulation of counteraction to persons classified as "thieves in laws" in Ukraine]. Naukovyi visnyk Khersonskoho derzhavnoho universytetu, 6(3), 73-79. (in Ukrainian) Onyshchuk, O. O. (2011). Deiaki pytannia komparatyvistyky u sferi zapobihannia protydii koruptsii [Some issues of comparative anti-corruption prevention]. Yurydychnyi visnyk Prychornomoria, 2(2), 174-184. (in Ukrainian)

Pohoretskyi, M.A. (2007). Orhanizovana zlochynnist v Ukraini: tendentsii rozvytku ta zakhody protydii [Organized crime in Ukraine: Development trends and measures of counteraction]. Borotba $z$ orhanizovanoiu zlochynnistiu $i$ koruptsiieiu (teoriia i praktyka), 16, 99-110. (in Ukrainian)

Pavlenko, S. O. (2017). Taktyka vyiavlennia orhanizovanoi zlochynnosti z korumpovanymy zviazkamy [Tactics of Detection of Organized Crime with Corrupt Bonds] Proceedings from II International Scientific and Practical Conference on Implementation of State Anti-Corruption Policy in the International Dimension (pp. 307-310). (Kyiv, December 8, 2017). (Kyiv, June 23, 2017). V. V. Cherniei, S. D. Husariev, S. S. Cherniavskyi et al. (Eds.). Kyiv: National Academy of Internal Affairs. (in Ukrainian)

Dzhuzha, O. M. (2007). Orhanizovana zlochynnist v Ukraini ta krainakh Yevropy: posibnyk [Organized crime in Ukraine and European countries: A teaching manual]. Kyiv: National Academy of Internal Affairs. (in Ukrainian)

Pavlenko, S. O. (2013). Deiaki osoblyvosti protydii khabarnytstvu, vchynenomu sluzhbovymy osobamy, yaki zaymaiut vidpovidalne stanovyshche [Some features of combating bribery committed by officials who occupy a responsible position]. Borotba z orhanizovanoiu zlochynnistiu i koruptsiieiu (teoriia i praktyka): nauk.-prakt. zhurn, 2(30), 279-288. (in Ukrainian)

Lytvynov, O. M. (Ed.). (2015). Kryminolohiia: pytannia ta vidpovidi [Criminology: questions and answers]. Kh.: Zolota mylia.

Sevruk, V. H. (2017). Pravookhoronni orhany, yaki zdiysniuiut protydiiu zlochynam, shcho vchyniaiutsia orhanizovanymy hrupamy i zlochynnymy orhanizatsiiamy, yaki sformovani na etnichniy osnovi: ukrainskyi ta mizhnarodnyi dosvid [Law enforcement agencies that deal with crimes committed by organized groups and criminal organizations formed on an ethnic basis: Ukrainian and international experience]. Molodyi vchenyi, 11(51), 995-1005. (in Ukrainian)

Muntiian, V. I. (1999). Ekonomichna bezpeka Ukrainy [Economic security of Ukraine] (Monograph). K.: Publishing House NISSA under the President of Ukraine. (in Ukrainian)

The Financial Times (June 09, 2011). Europe: Hidden economy.

WEU Council of Ministers. (November 14, 1995). European Security: A Common Security Concept of the 27 WEU. Madrid.

Onyshchenko, S. V., Lapinskyi, I. E. (2013). Mizhnarodnyi dosvid borotby z tinizatsiieiu ekonomiky v umovakh hlobalizatsii [International experience in combating the shadow economy in a globalized world]. Efektyvna ekonomika, 2. Retrieved from: http://nbuv.gov.ua/UJRN/efek_2013_2_76 (in Ukrainian)

Etnicheskaia orhanyzovannaia prestupnost [Ethnic organized crime]. Retrieved from: http://magspace.ru/ blog/218625.html (in Russian)

Sevruk, V.H. (2018). Special international law enforcement structures (bodies) that combat against crime exercised by organized groups and criminal organizations established on an ethnic basis. Naukovyi visnyk Natsionalnoi akademii vnutrishnikh sprav, 2(107), 348-357. (in Ukrainian)

Yevropol [Europol]. Retrieved from: https://uk.wikipedia.org/wiki/\%D0\%84\%D0\%B2\%D1\%80\%D0\%BE\% $\mathrm{D} 0 \% \mathrm{BF} \% \mathrm{D} 0 \% \mathrm{BE} \% \mathrm{D} 0 \% \mathrm{BB}$

Further: Council Document 11037/ of July 0582005 available. Retrieved from: http://register.consilium.europa.eu/ pdf/en/05/st11/st1103.en05.pdf

Konventsiia OON proty transnatsionalnoi orhanizovanoi zlochynnosti [UN Convention against Transnational Organized Crime of November 15, 2000] (Editorial of February 4, 2004). Retrieved from: http: //zakon.rada.gov.ua/ cgi-in/laws/main.cgi?nreg=995_789\&p=1228117189160723//

Repetskaia, A. L. (2001). Transnatsionalnaia orhanyzovannaia prestupnost: kharakterystyka, prychyny, stratehyi kontrolia [Transnational organized crime: Characteristics, causes, control strategies]. Irkutsk. (in Russian)

Aromaa, K. (2006). European experiences in preventing organised crime: Field studies of best practices by a Council of Europe Expert Group. European Institute for Crime Prevention and Control, affiliated with the United Nations, 50, 13-33.

Shostko, O. Yu. (2007). Konfiskatsiia maina yak efektyvna stratehiia protydii naibilsh nebezpechnym zlochynam [Confiscation of property as an effective strategy for counteracting the most dangerous crimes]. Borotba $z$ orhanizovanoiu zlochynnistiu i koruptsiieiu (teoriia i praktyka): nauk.-prakt. zhurn, 16, 220-230. (in Ukrainian) 
Shostko, O. Yu. (2008). Administratyvnyi pidkhid do problemy protydii orhanizovaniy zlochynnosti u Niderlandakh [Administrative approach to the problem of combating organized crime in the Netherlands]. Borotba z orhanizovanoiu zlochynnistiu i koruptsiieiu (teoriia i praktyka): nauk.-prakt. zhurn, 18, 108-118. (in Ukrainian)

Martynov, M. D. (2010). Suchasni problemy orhanizatsii diialnosti orhaniv vnutrishnikh sprav Ukrainy ta shlyakhy ikh vyrishennia [Modern problems of organization of the activity of Internal Affairs bodies of Ukraine and ways of their solution]. Forum prava, 3, 290-296. Retrieved from: http://www.nbuv.gov.ua/ejournals/FP/20103/10mmdsiv.pdf (in Ukrainian)

Dolia, L. M. (2001). Legalization ("laundering") the proceeds of crime as an international problem. Borotba $z$ orhanizovanoiu zlochynnistiu i koruptsiieiu (teoriia i praktyka): nauk.-prakt. zhurn, 4, 51-56.

Kryvonos, L. V. (2014). Mizhnarodnyi dosvid derzhavnykh mekhanizmiv zapobihannia ta protydii lehalizatsii (vidmyvannia) dokhodiv, otrymanykh zlochynnym shliakhom [International experience in state mechanisms for prevention and counteraction to legalization (laundering) of proceeds from crime]. Derzhavne upravlinnia: udoskonalennia ta rozvytok, 6. Retrieved from: http://www.dy.nayka.com.ua/?op=1\&z=730 (in Ukrainian)

Cabinet of Ministers of Ukraine and the National Bank of Ukraine. On the forty recommendations of the financial action task force on money laundering (FATF) (Resolution no. 1124 of August 28, 2001 as amended on April 20, 2004), Ofitsiynyi visnyk Ukrainy, 35, 63-68.

Osyka, I. M. (2003). Protydiia ekonomichnii zlochynnosti: ohliad mizhnarodnoho naukovo-praktychnoho seminaru [Counteraction to economic crime: Review of international scientific workshop]. Pravo i bezpeka, 2(2) 213-219. (in Ukrainian)

Volynets, V. V. (2014). Systema borotby z orhanizovanoiu zlochynnistiu u SshA (dosvid orhanizatsii ta funktsionuvannia) [The system of combating organized crime in the USA (the experience of organization and functioning)]. Borotba $z$ orhanizovanoiu zlochynnistiu i koruptsiieiu (teoriia i praktyka): nauk.-prakt. zhurn, 1, 72-74. (in Ukrainian)

Polovynskyi, L. V. (2008). Protydiia lehalizatsii (vidmyvanniu) dokhodiv, oderzhanykh zlochynnym shliakhom: mizhnarodnyi ta vitchyznianyi dosvid [Counteraction to legalization (laundering) of proceeds from crime: International and domestic experience]. Ekonomika. Finansy. Pravo, 5, 33-35. (in Ukrainian)

Zhuravel, M. I. (2010). Mizhnarodni pravovi aspekty borotby z lehalizatsiieiu dokhodiv zdobutykh zlochynnym shliakhom [International legal aspects of combating the legalization of proceeds from crime]. Chasopys Kyivskoho universytetu prava, 1, 280-286. (in Ukrainian)

Yehorycheva, S. B. (2014). Orhanizatsiia finansovoho monitorynhu v bankakh: Navchalnyi posibnyk [Organization of financial monitoring in banks a teaching manual]. K.: Center for Educational Literature. (in Ukrainian)

Kravchuk, S. (2010). Pryiniattia i realizatsiia kontseptsii borotby zi zlochynnistiu u sferi ekonomiky - shliakh do prypynennia ekonomichnoi zlochynnosti [Adoption and implementation of the concept of combating crime in the economy: The path to the cessation of economic crime]. Pravo Ukrainy, 7, 151-156. (in Ukrainian)

Zhukovska, Zh. O. (2008). Problemy mizhnarodnoho spivtovarystva u borotbi zi zlochynamy maynovoho kharakteru [Problems of the international community in countering property-related crimes]. Pivdennoukrainskyi pravochyn chasopys, 4, 35-36. (in Ukrainian)

Zhuravka, F. O. (2008). Valiutna polityka v umovakh transformatsiynykh zmin ekonomiky [Currency policy in conditions of transformational economic changes] (Monograph). Sumy: "KVK "Business Perspectives" LLC, "UAB NBU". (in Ukrainian)

Kolesnikov V. I. (1999). Problemy valiutnogo regulirovaniia v stranakh s rynochnoi ekonomikoi [Problems of currency regulation in market economy countries] / V. I. Kolesnikov, A. I. Shmyreva, A. Yu. Klimov. Novosibirsk.

TRACFIN (Official site). Retrieved from: http://www.economie.gouv.fr/tracfin

Kovalenko, V. V., Dmytrov, S. O., Yezhov, A. V. (2007). Mizhnarodnyi dosvid u sferi zapobihannia ta protydii vidmyvanniu dokhodiv, oderzhanykh zlochynnym shliakhom, ta finansuvanniu teroryzmu [International experience in the field of prevention and counteraction to laundering of proceeds from crime and terrorist financing] (Monograph). Sumy: "UAB NBU". (in Ukrainian)

Parshutin, A. B. (2015). Wspótpraca Europejska [European Cooperation], 3(3), 105-113.

Sevruk, V. (2016). Ethnic crime in Ukraine. Yurydychnyi chasopys Natsionalnoi akademii vnutrishnikh sprav [Legal Journal of the National Academy of Internal Affairs], 1(11), 73-83. (in Ukrainian)

Androsovych, L. H. (2018). Orhanizovana zlochynnist u finansoviy systemi: suchasnyi etap ta tendentsii [Organized crime in the financial system: the current stage and trends]. Naukovyi visnyk publichnoho ta pryvatnoho prava, 2, 215-224.

Pavlenko, S. O. (2015). Dukhovnist i moralnyi kontrol yak umova zapobihannia ta protydii koruptsii [Spirituality and moral control as a condition for preventing and combating corruption]. Proceedings from Scientific and Practical Conference Legal psychology in Ukraine: achievements and perspectives (vol. 2, pp. 86-89). (Kiev, March 26, 2015). V. V. Cherniei, M. V. Kostytskyi, O. I. Kudermin et al. (Eds.). Kyiv: National Academy of Internal Affairs. (in Ukrainian) 